\title{
ELECTROPHORETIC STUDIES OF SYNOVIAL FLUID PROTEINS*
}

\author{
BY \\ MATTHEW WILKINSON† AND BRIAN S. JONES \\ From the Clinical Research Department, Charing Cross Hospital, and the Department of Pathology, \\ St. Bartholomew's Hospital, London
}

During the past 4 years all synovial fluids taken for examination have been submitted to electrophoresis on paper for estimation of the different protein fractions. A sufficient number has now been examined to allow a more detailed analysis of the results than was possible in our earlier report (Wilkinson and Jones, 1962).

\section{Material and Methods}

Paper electrophoretic studies were made on serum and synovial fluid from one or both knees of patients with the diagnoses listed in Table $I$, using the methods previously described (Wilkinson and Jones, 1962).

The diagnoses were established from the clinical and radiological features, but in addition successful needle biopsies were available from more than half the patients as indicated in Table I. In order that the histological features could be correlated with the synovial fluid changes, each biopsy was studied by one observer (B.S.J.) without knowledge of the clinical or biochemical details. Particular attention was paid to the degree of synoviocyte hyperplasia, vascularity, lymphocyte infiltration, and plasma cell infiltration, and each of these features was graded,+++ , or +++ , to facilitate comparisons.

TABLE I

PATIENTS STUDIED AND SPECIMENS ANALYSED

\begin{tabular}{c|c|c|c|c}
\hline Disease & $\begin{array}{c}\text { No. } \\
\text { of } \\
\text { Patients }\end{array}$ & $\begin{array}{c}\text { No. } \\
\text { of } \\
\text { Sera }\end{array}$ & $\begin{array}{c}\text { No. of } \\
\text { Synovial } \\
\text { Fluids }\end{array}$ & $\begin{array}{c}\text { No. of } \\
\text { Synovial } \\
\text { Biopsies }\end{array}$ \\
\hline Osteo-arthritis $\quad$. & 40 & 45 & 46 & 28 \\
\hline Traumatic Synovitis & 11 & 11 & 11 & 2 \\
\hline Rheumatoid Arthritis & 52 & 67 & 79 & 42 \\
\hline Ankylosing Spondylitis & 5 & 5 & 6 & 5 \\
\hline Reiter's Syndrome .. & 3 & 7 & 8 & 6 \\
\hline
\end{tabular}

* Paper read to the Heberden Society on December 7, 1963

+ Present address: Bridge of Earn Hospital, Perthshire, Scotland.
Latex-agglutination or Waaler-Rose tests were available on serum, and sometimes also on synovial fluids, from all except one patient with rheumatoid arthritis and from all patients with ankylosing spondylitis and Reiter's syndrome, but only a minority of patients with osteoarthritis and traumatic synovitis were tested.

Students " $t$ " test was again used for all statistical comparisons.

\section{Results}

The mean values (in $\mathrm{g}$. per cent.) of the various serum and synovial fluid protein fractions for each disease group are shown in Table II (opposite).

Although we have made a few estimations on specimens from cases of gout, rheumatic fever, leukaemia, sarcoidosis, and neuropathic arthritis, only those diseases in which several estimations are available will be considered in the main analysis.

\section{Osteo-arthritis}

When these cases were classified according to the duration of the synovial effusion before aspiration, the following trends emerged (Table III, opposite).

Cases with recent synovial effusions showed significantly higher serum alpha $a_{2}$ and gamma globulin and consequently total protein levels, and the levels were lower in cases with effusions of longer duration. The synovial fluids showed similar trends though at lower protein levels.

Even in synovial fluids of less than 2 weeks' duration, however, the gamma globulin levels were never very high, and in the whole series only six of the 45 osteo-arthritic fluids examined contained more than $1 \mathrm{~g}$. per cent. Four of these came from patients with effusions that had been present for less than 2 weeks.

A successful needle biopsy was taken from 28 osteo-arthritic joints at the time of aspiration and an attempt was made to correlate the histological changes with the various characteristics of the synovial fluid. Neither the vascularity of the 
TABLE II

MEAN VALUES FOR SERUM AND SYNOVIAL FLUID PROTEIN FRACTIONS IN DIFFERENT JOINT DISEASES

Statistical comparisons have been made between the figures for osteo-arthritis and those for each other disease group.

\begin{tabular}{|c|c|c|c|c|c|c|c|c|c|c|c|c|c|c|}
\hline \multirow{3}{*}{ Diagnosis } & \multicolumn{7}{|c|}{ Serum Proteins (g. per cent.) } & \multicolumn{7}{|c|}{ Synovial Fluid Proteins (g. per cent.) } \\
\hline & \multirow{2}{*}{$\begin{array}{c}\text { No. of } \\
\text { Samples }\end{array}$} & \multirow{2}{*}{$\begin{array}{c}\text { Total } \\
\text { Protein }\end{array}$} & \multirow{2}{*}{$\underset{\text { min }}{\text { Albu- }}$} & \multicolumn{4}{|c|}{ Globulin } & \multirow{2}{*}{$\begin{array}{c}\text { No. of } \\
\text { Samples }\end{array}$} & \multirow{2}{*}{$\begin{array}{c}\text { Total } \\
\text { Protein }\end{array}$} & \multirow{2}{*}{$\underset{\text { min }}{\text { Albu- }}$} & \multicolumn{4}{|c|}{ Globulin } \\
\hline & & & & $\alpha^{1}$ & $\alpha^{2}$ & $\beta$ & $\gamma$ & & & & $\alpha^{1}$ & $\alpha^{2}$ & $\beta$ & $\gamma$ \\
\hline Osteo-arthritis $\ldots$ & 45 & $6 \cdot 88$ & $3 \cdot 32$ & $0 \cdot 32$ & $0 \cdot 7$ & 0.92 & $1 \cdot 63$ & 46 & $3 \cdot 74$ & $2 \cdot 05$ & $0 \cdot 17$ & $0 \cdot 28$ & 0.42 & $0 \cdot 81$ \\
\hline Traumatic Synovitis & 11 & $7 \cdot 38 *$ & $3 \cdot 65^{*}$ & $0 \cdot 32$ & $0 \cdot 76$ & $0 \cdot 85$ & $1 \cdot 78$ & 11 & $4 \cdot 3$ & $2 \cdot 45^{*}$ & $0 \cdot 18$ & $0 \cdot 29$ & 0.45 & 0.94 \\
\hline Rheumatoid Arthritis .. & 67 & $6 \cdot 88$ & $2 \cdot 78 \ddagger$ & $0.4 \ddagger$ & $0.89 \ddagger$ & $0 \cdot 87$ & $1 \cdot 94 \dagger$ & 79 & $4 \cdot 76 \neq$ & $1 \cdot 98$ & $0 \cdot 27 \ddagger$ & $0.45 t$ & $0 \cdot 54 t$ & $1 \cdot 52 \ddagger$ \\
\hline Ankylosing Spondylitis. . & 5 & $8 \cdot 39 \ddagger$ & $2 \cdot 98^{*}$ & $0 \cdot 39$ & $1 \cdot 07 \ddagger$ & 0.94 & $3 \cdot 01 \ddagger$ & 6 & $6 \cdot 55 \dagger$ & $2 \cdot 3$ & $0 \cdot 24$ & $0 \cdot 52 \ddagger$ & $0 \cdot 64 \ddagger$ & $2 \cdot 82 \ddagger$ \\
\hline Reiter's Syndrome & 7 & $7 \cdot 5^{*}$ & $3 \cdot 37$ & $0 \cdot 42 *$ & $0.91 \dagger$ & $0 \cdot 77$ & $2 \cdot 03+$ & 8 & $5 \cdot 12 \ddagger$ & $2 \cdot 51 \dagger$ & $0 \cdot 24$ & $0.46 \ddagger$ & 0.5 & $1 \cdot 39 \ddagger$ \\
\hline
\end{tabular}

Significant differences are indicated as follows: $*<0.05,+<0.01, \ddagger<0.001$.

TABLE III

SERUM AND SYNOVIAL FLUID PROTEINS IN OSTEO-ARTHRITIS CLASSIFIED BY DURATION OF EFFUSION Statistical comparisons have been made against the cases with effusions of less than 2 weeks' duration.

\begin{tabular}{|c|c|c|c|c|c|c|c|c|c|c|c|c|c|c|}
\hline \multirow{3}{*}{$\begin{array}{l}\text { Duration of } \\
\text { Effusion } \\
\text { (wks) }\end{array}$} & \multicolumn{7}{|c|}{ Serum Proteins (g. per cent.) } & \multicolumn{7}{|c|}{ Synovial Fluid Proteins (g. per cent.) } \\
\hline & \multirow{2}{*}{$\begin{array}{c}\text { No. of } \\
\text { Samples }\end{array}$} & \multirow{2}{*}{$\begin{array}{c}\text { Total } \\
\text { Protein }\end{array}$} & \multirow{2}{*}{$\begin{array}{c}\text { Albu- } \\
\text { min }\end{array}$} & \multicolumn{4}{|c|}{ Globulin } & \multirow{2}{*}{$\begin{array}{c}\text { No. of } \\
\text { Samples }\end{array}$} & \multirow{2}{*}{$\begin{array}{c}\text { Total } \\
\text { Protein }\end{array}$} & \multirow{2}{*}{$\begin{array}{c}\text { Albu- } \\
\text { min }\end{array}$} & \multicolumn{4}{|c|}{ Globulin } \\
\hline & & & & $\alpha^{1}$ & $\alpha^{2}$ & $\beta$ & $\gamma$ & & & & $\alpha^{1}$ & $\alpha^{2}$ & $\beta$ & $\gamma$ \\
\hline$<2$ & 9 & $7 \cdot 23$ & $3 \cdot 23$ & $0 \cdot 32$ & $0 \cdot 79$ & $0 \cdot 99$ & $1 \cdot 9$ & 9 & $4 \cdot 19$ & $2 \cdot 15$ & $0 \cdot 17$ & $0 \cdot 34$ & 0.52 & $1 \cdot 01$ \\
\hline $2-12$ & 19 & $6 \cdot 8$ & $3 \cdot 41$ & $0 \cdot 28$ & 0.68 & $0 \cdot 87$ & $1 \cdot 57$ & 20 & $3 \cdot 76$ & $2 \cdot 08$ & $0 \cdot 16$ & 0.29 & 0.41 & $0 \cdot 77 \dagger$ \\
\hline$>12$ & 17 & $6 \cdot 79$ & $3 \cdot 28$ & $0 \cdot 36$ & $0.66^{*}$ & 0.93 & $1 \cdot 56^{*}$ & 17 & $3 \cdot 5^{*}$ & $1 \cdot 97$ & $\overline{0 \cdot 18}$ & $0 \cdot 24 *$ & $0 \cdot 38$ & $0.75 t$ \\
\hline
\end{tabular}

* †Significant differences indicated as in Table II.

synovial membrane nor the degree of synoviocyte hyperplasia showed any correlation with the fluid volume, total protein content, or duration of effusion. While there may indeed be no such correlations, it is also possible that the small biopsies failed to represent the rather variable synovial patterns (Cruickshank, 1952) and that this obscured any relationships.

\section{Traumatic Synovitis}

In this group only synovial fluids free from blood were examined.

A comparison of the sera of these patients with the sera from osteo-arthritic patients (Table II) showed higher total protein, albumin, and gamma globulin levels, though only the first two differences were statistically significant. The higher serum albumin level may possibly depend on the younger age of these patients, several of whom were fit young athletes with cartilage injuries. Similar differences were seen when the synovial fluids were compared.
If the mean protein values for the cases of traumatic synovitis (Table II) are compared with those for the cases of osteo-arthritis with effusions for less than 2 weeks (Table III), the similarity is rather striking. This similarity would be consistent with the thesis that effusions into osteo-arthritic joints are simply due to minor injuries sustained by an unstable joint. As the inflammatory reaction subsides, the globulin changes in the blood no doubt revert towards normal. The synovial fluid changes presumably reflect the plasma changes and also, as the inflammation and hyperaemia subside, the synovial membrane becomes less permeable and the synovial fluid protein levels fall to a lower equilibrium with the plasma.

Synovial biopsies were taken from only two patients with traumatic synovitis, but the histological changes were indistinguishable from those seen in osteo-arthritis with effusion, when a surprising degree of hyperaemia may sometimes be observed in the synovial membrane (Wilkinson and Jones, 1963). 


\section{Rheumatoid Arthritis}

Of the 52 patients in this group, 37 were cases of classical, thirteen of definite, and two of probable rheumatoid arthritis, according to the revised criteria of the American Rheumatism Association (Ropes, Bennett, Cobb, Jacox, and Jessar, 1959).

In Table II the mean protein levels for all rheumatoid arthritic sera and synovial fluids can be compared with sera from patients with osteo-arthritis and traumatic synovitis. The rheumatoid sera showed very significant differences, namely, a lower albumin level and higher values for all globulin fractions except beta globulin. The rheumatoid synovial fluids contained significantly more protein than the traumatic and osteo-arthritic fluids, but the mean albumin level, though significantly less than that in traumatic synovitis, did not differ greatly from the mean level in osteo-arthritis, especially in cases with longstanding effusions (Table VI). Possibly any increased permeability of the synovial membrane in rheumatoid arthritis which would tend to increase the synovial fluid albumin content was counterbalanced by the lower serum albumin level which would tend to produce a lower synovial fluid albumin level.

Although the rheumatoid sera contained significantly more gamma globulin than the osteoarthritic sera, the difference in the synovial fluid levels was far more marked. This disproportionately high concentration of gamma globulin in rheumatoid synovial fluids strongly favours the theory of the local synthesis of gamma globulin in the synovial membrane (Wilkinson and Jones, 1962). Of the 79 rheumatoid synovial fluids examined, only three contained less than $1 \mathrm{~g}$. per cent. gamma globulin, and these were from patients with disease of recent onset.

In such a chronic disease it would be surprising if the protein patterns remained constant, and in
Table IV the mean protein levels in serum and synovial fluid are presented according to the duration of the rheumatoid arthritis. If the osteoarthritic serum protein values are taken as the nearest approach to normal values available in this study (Table II), then the rheumatoid sera taken within 3 months of the onset of the disease showed significantly lower albumin levels $(P<0.01)$ and higher alpha $_{2}$ globulin levels $(P<0.001)$, but the alpha $_{1}$ globulin levels, though higher, did not reach statistical significance. The serum gamma globulin levels at this stage were surprisingly low. With increasing duration of disease the rheumatoid sera showed somewhat higher total protein, falling alpha $_{2}$ globulin, and rising gamma globulin levels. Similar trends were seen in the synovial fluid with the addition of steadily increasing albumin content. The statistically significant changes are indicated in Table IV, but by far the most significant change was the rising gamma globulin in the synovial fluid with increasing duration of disease.

Another possible influence upon the protein patterns was corticosteroid therapy and since few cases of recent onset were so treated compared with almost half of the longstanding cases, the 43 sera and 49 synovial fluids taken from patients not under corticosteroid treatment were analysed separately (Table V, opposite).

The same changes were observed with increasing duration of disease as have already been described. However, these drugs do have some effect on the protein patterns.

In Table VI (opposite) the mean values for the serum and synovial fluids from steroid-treated cases is compared with those from patients not receiving corticosteroids. Since only one patient who had had rheumatoid arthritis for less than one year at the time of aspiration was receiving these drugs, the comparison is confined to cases with disease of

TABLE IV

SERUM AND SYNOVIAL FLUID PROTEINS IN RHEUMATOID ARTHRITIS CLASSIFIED BY DURATION OF DISEASE Statistical comparisons have been made against the cases of less than 3 months' duration.

\begin{tabular}{|c|c|c|c|c|c|c|c|c|c|c|c|c|c|c|}
\hline \multirow{3}{*}{$\begin{array}{c}\text { Duration } \\
\text { of } \\
\text { Disease }\end{array}$} & \multicolumn{7}{|c|}{ Serum Proteins (g. per cent.) } & \multicolumn{7}{|c|}{ Synovial Fluid Proteins (g. per cent.) } \\
\hline & \multirow{2}{*}{$\begin{array}{l}\text { No. of } \\
\text { Samples }\end{array}$} & \multirow{2}{*}{$\underset{\text { Protein }}{\text { Total }}$} & \multirow{2}{*}{$\underset{\text { min }}{\text { Albu- }}$} & \multicolumn{4}{|c|}{ Globulin } & \multirow{2}{*}{$\begin{array}{c}\text { No. of } \\
\text { Samples }\end{array}$} & \multirow{2}{*}{$\begin{array}{l}\text { Total } \\
\text { Protein }\end{array}$} & \multirow{2}{*}{$\underset{\text { min }}{\text { Albu- }}$} & \multicolumn{4}{|c|}{ Globulin } \\
\hline & & & & $\alpha^{1}$ & $\alpha^{2}$ & $\beta$ & $\gamma$ & & & & $\alpha^{1}$ & $\alpha^{2}$ & $\beta$ & $\gamma$ \\
\hline$<3 \mathrm{mths}$ & 6 & $6 \cdot 52$ & $2 \cdot 71$ & 0.41 & $1 \cdot 06$ & 0.89 & $1 \cdot 44$ & 6 & $4 \cdot 2$ & $1 \cdot 75$ & $0 \cdot 26$ & 0.62 & $0 \cdot 53$ & $1 \cdot 04$ \\
\hline $3-12 \mathrm{mths}$ & 7 & $6 \cdot 88$ & $2 \cdot 78$ & 0.43 & $0 \cdot 89$ & $0 \cdot 79$ & $1 \cdot 99$ & 8 & $4 \cdot 61$ & $1 \cdot 97$ & $0 \cdot 29$ & 0.5 & $0 \cdot 51$ & $1 \cdot 34^{*}$ \\
\hline $1-5$ yrs & 28 & $6 \cdot 98$ & $2 \cdot 69$ & 0.41 & 0.9 & 0.92 & $2 \cdot 06^{*}$ & 32 & $4 \cdot 91^{*}$ & $1 \cdot 97$ & $0 \cdot 29$ & 0.48 & $0 \cdot 59$ & $1 \cdot 58 \dagger$ \\
\hline$>5$ yrs & 26 & $6 \cdot 89$ & $2 \cdot 88$ & $0 \cdot 37$ & 0.85 & 0.84 & 1.92 & 33 & $4 \cdot 75$ & $2 \cdot 02$ & $0 \cdot 25$ & $0 \cdot 37 \dagger$ & 0.51 & $1 \cdot 6^{*}$ \\
\hline
\end{tabular}


TABLE V

SERUM AND SYNOVIAL FLUID PROTEINS IN RHEUMATOID ARTHRITIS NOT TREATED BY CORTICOSTEROIDS, CLASSIFIED BY DURATION OF DISEASE

Statistical comparisons have been made against the cases of less than 3 months' duration.

\begin{tabular}{|c|c|c|c|c|c|c|c|c|c|c|c|c|c|c|}
\hline \multirow{3}{*}{$\begin{array}{c}\begin{array}{c}\text { Duration } \\
\text { of } \\
\text { Disease }\end{array}\end{array}$} & \multicolumn{7}{|c|}{ Serum Protein (g. per cent.) } & \multicolumn{7}{|c|}{ Synovial Fluid Proteins (g. per cent.) } \\
\hline & \multirow{2}{*}{$\begin{array}{c}\text { No. of } \\
\text { Samples }\end{array}$} & \multirow{2}{*}{$\begin{array}{c}\text { Total } \\
\text { Protein }\end{array}$} & \multirow{2}{*}{$\underset{\text { min }}{\text { Albu- }}$} & \multicolumn{4}{|c|}{ Globulin } & \multirow{2}{*}{$\begin{array}{c}\text { No. of } \\
\text { Samples }\end{array}$} & \multirow{2}{*}{$\begin{array}{c}\text { Total } \\
\text { Protein }\end{array}$} & \multirow{2}{*}{$\underset{\text { min }}{\text { Albu- }}$} & \multicolumn{4}{|c|}{ Globulin } \\
\hline & & & & $\alpha 1$ & $\alpha^{2}$ & $\beta$ & $\gamma$ & & & & $\alpha^{1}$ & $\alpha^{2}$ & $\beta$ & $\gamma$ \\
\hline$<3$ mths & 6 & $6 \cdot 52$ & $2 \cdot 71$ & 0.41 & $1 \cdot 06$ & $0 \cdot 89$ & $1 \cdot 44$ & 6 & $4 \cdot 2$ & $1 \cdot 75$ & $0 \cdot 26$ & 0.62 & $0 \cdot 53$ & $1 \cdot 04$ \\
\hline $3-12 \mathrm{mths}$ & 6 & $6 \cdot 8$ & $2 \cdot 81$ & $0 \cdot 41$ & 0.91 & $0 \cdot 79$ & $1 \cdot 88$ & 7 & $4 \cdot 57$ & $1 \cdot 99$ & $0 \cdot 26$ & $0 \cdot 5$ & $0 \cdot 5$ & $1 \cdot 32$ \\
\hline $1-5$ yrs & 15 & 7.06 & $2 \cdot 64$ & 0.43 & 0.93 & 0.91 & $2 \cdot 16^{*}$ & 17 & $5 \cdot 08^{*}$ & $1 \cdot 94$ & $0 \cdot 32$ & 0.56 & 0.61 & $1 \cdot 64^{*}$ \\
\hline$>5 \mathrm{yrs}$ & 16 & $6 \cdot 96$ & $3 \cdot 05$ & $0 \cdot 33$ & $0 \cdot 78 \ddagger$ & $0 \cdot 8$ & $2 \cdot 01$ & 19 & $4 \cdot 71$ & $2 \cdot 07$ & $0 \cdot 24$ & $0 \cdot 36 \ddagger$ & $0 \cdot 47$ & 1.57 \\
\hline
\end{tabular}

* + Significant differences indicated as in Table II.

TABLE VI

SERUM AND SYNOVIAL FLUID PROTEINS IN RHEUMATOID ARTHRITIS WITH AND WITHOUT CORTICOSTEROID THERAPY

\begin{tabular}{|c|c|c|c|c|c|c|c|c|c|c|c|c|c|c|c|}
\hline \multirow{3}{*}{$\begin{array}{c}\text { Duration } \\
\text { of } \\
\text { Disease } \\
\text { (yrs) }\end{array}$} & \multirow{3}{*}{$\begin{array}{l}\text { Steroid } \\
\text { Therapy }\end{array}$} & \multicolumn{7}{|c|}{ Serum Proteins (g. per cent.) } & \multicolumn{7}{|c|}{ Synovial Fluid Proteins (g. per cent.) } \\
\hline & & \multirow{2}{*}{$\begin{array}{c}\text { No. of } \\
\text { Samples }\end{array}$} & \multirow{2}{*}{$\begin{array}{c}\text { Total } \\
\text { Protein }\end{array}$} & \multirow{2}{*}{$\begin{array}{c}\text { Albu- } \\
\text { min }\end{array}$} & \multicolumn{4}{|c|}{ Globulin } & \multirow{2}{*}{$\begin{array}{c}\text { No. of } \\
\text { Samples }\end{array}$} & \multirow{2}{*}{$\begin{array}{c}\text { Total } \\
\text { Protein }\end{array}$} & \multirow{2}{*}{$\underset{\text { min }}{\text { Albu- }}$} & \multicolumn{4}{|c|}{ Globulin } \\
\hline & & & & & $\alpha^{1}$ & $\alpha^{2}$ & $\beta$ & $\gamma$ & & & & $\alpha^{1}$ & $\alpha^{2}$ & $\beta$ & $\gamma$ \\
\hline $1-5$ & $\begin{array}{l}\text { Yes } \\
\text { No }\end{array}$ & $\begin{array}{l}13 \\
15\end{array}$ & $\begin{array}{l}6 \cdot 89 \\
7 \cdot 06 \\
\end{array}$ & $\begin{array}{l}2 \cdot 75 \\
2 \cdot 64\end{array}$ & $\begin{array}{l}0.4 \\
0.43\end{array}$ & $\begin{array}{l}0.87 \\
0.93\end{array}$ & $\begin{array}{l}0.93 \\
0.91\end{array}$ & $\begin{array}{l}1.94 \\
2.16\end{array}$ & $\begin{array}{l}15 \\
17\end{array}$ & $\begin{array}{l}4 \cdot 72 \\
5 \cdot 08 \dagger\end{array}$ & $\begin{array}{l}2 \cdot 0 \\
1 \cdot 94\end{array}$ & $\begin{array}{l}0.25 \\
0.32\end{array}$ & $\begin{array}{l}0 \cdot 39 \\
0 \cdot 56 \ddagger\end{array}$ & $\begin{array}{l}0.57 \\
0.61\end{array}$ & $\begin{array}{l}1 \cdot 51 \\
1.64\end{array}$ \\
\hline$>5$ & $\begin{array}{l}\text { Yes } \\
\text { No }\end{array}$ & $\begin{array}{l}10 \\
16\end{array}$ & $\begin{array}{l}6 \cdot 71 \\
6.96\end{array}$ & $\begin{array}{l}2 \cdot 6 \\
3.05\end{array}$ & $\begin{array}{l}0.45 \\
0.33\end{array}$ & $\begin{array}{l}0.96 \\
0.78\end{array}$ & $\begin{array}{l}0.92 \\
0.8\end{array}$ & $\begin{array}{l}1.78 \\
2.01\end{array}$ & $\begin{array}{l}14 \\
19\end{array}$ & $\begin{array}{l}4 \cdot 79 \\
4 \cdot 71\end{array}$ & $\begin{array}{l}1.96 \\
2.07\end{array}$ & $\begin{array}{l}0 \cdot 25 \\
0.24\end{array}$ & $\begin{array}{l}0.38 \\
0.36\end{array}$ & $\begin{array}{l}0.56 \\
0.47\end{array}$ & $\begin{array}{l}1 \cdot 64 \\
1 \cdot 57\end{array}$ \\
\hline
\end{tabular}

$\dagger$ Significant differences indicated as in Table II.

more than one year's duration. In steroid-treated patients the serum gamma globulin levels appeared to be lower, but this difference was not quite significant. In the synovial fluids of cases of rheumatoid arthritis treated with steroids for 1-5 years, the total proteins were significantly lower, the alpha ${ }_{2}$ globulins suspiciously lower. Rather surprisingly these differences were not found in the group of patients who had had rheumatoid arthritis for more than 5 years. Perhaps this may be related to the increasing difficulty in controlling the disease with these drugs after long periods of administration and the tendency to use lower doses because of increasing side-effects.

During the analysis it was noticed that those patients with the highest gamma globulin levels in the serum and synovial fluid were usually patients in whom the tests for rheumatoid factor were negative. Of eight patients with more than $2 \mathrm{~g}$. per cent. gamma globulin in the synovial fluid only one had a positive test. Therefore the mean protein values for patients with a positive test for rheumatoid factor were compared with those for patients showing negative tests. Since the majority of cases of short duration gave negative tests at the time of aspiration and adequate follow-up tests were not always possible, the comparison was confined to patients who had had rheumatoid arthritis for more than one year.

Table VII (overleaf) shows that, in both serum and synovial fluid, the gamma globulin levels were higher in patients with negative tests, but only in the synovial fluid was this difference statistically significant.

An attempt was made to correlate the histological changes in the biopsies from 42 rheumatoid joints with the synovial fluid characteristics. There was no correlation between synovial membrane vascularity and fluid volume, but increasing vascularity showed a rather doubtful correlation with increasing synovial fluid protein content. Somewhat more suggestive was a correlation between the intensity of plasma cell infiltration and increasing synovial 

RHEUMATOID ARTHRITIS

\begin{tabular}{|c|c|c|c|c|c|c|c|c|c|c|c|c|c|c|c|}
\hline \multirow{3}{*}{$\begin{array}{c}\text { Duration } \\
\text { of } \\
\text { Disease } \\
\text { (yrs) }\end{array}$} & \multirow{3}{*}{$\begin{array}{l}\text { Rheu- } \\
\text { matoid } \\
\text { Factor }\end{array}$} & \multicolumn{7}{|c|}{ Serum Proteins (g. per cent.) } & \multicolumn{7}{|c|}{ Synovial Fluid Proteins (g. per cent.) } \\
\hline & & \multirow{2}{*}{$\begin{array}{l}\text { No. of } \\
\text { Samples }\end{array}$} & \multirow{2}{*}{$\begin{array}{c}\text { Total } \\
\text { Protein }\end{array}$} & \multirow{2}{*}{$\underset{\text { min }}{\text { Albu- }}$} & \multicolumn{4}{|c|}{ Globulin } & \multirow{2}{*}{$\begin{array}{l}\text { No. of } \\
\text { Samples }\end{array}$} & \multirow{2}{*}{$\begin{array}{c}\text { Total } \\
\text { Protein }\end{array}$} & \multirow{2}{*}{$\underset{\text { min }}{\text { Albu- }}$} & \multicolumn{4}{|c|}{ Globulin } \\
\hline & & & & & $\alpha^{1}$ & $\alpha^{2}$ & $\beta$ & $\gamma$ & & & & $\alpha 1$ & $\alpha^{2}$ & $\beta$ & $\gamma$ \\
\hline \multirow[t]{2}{*}{$1-5$} & \multirow{2}{*}{$\begin{array}{c}\text { Sero- } \\
\text { positive } \\
\text { Sero- } \\
\text { negative }\end{array}$} & 17 & $6 \cdot 82$ & $2 \cdot 68$ & $0 \cdot 39$ & 0.91 & 0.9 & $1 \cdot 94$ & 20 & $4 \cdot 71+$ & $1 \cdot 95$ & $0 \cdot 28$ & 0.44 & $0 \cdot 58$ & $1 \cdot 45^{*}$ \\
\hline & & 10 & $7 \cdot 44$ & $2 \cdot 77$ & 0.47 & 0.93 & 0.98 & $2 \cdot 29$ & 11 & $5 \cdot 24$ & $1 \cdot 99$ & $0 \cdot 30$ & $0 \cdot 54$ & $0 \cdot 61$ & $1 \cdot 8$ \\
\hline \multirow[t]{2}{*}{$>5$} & \multirow{2}{*}{$\begin{array}{c}\text { Sero- } \\
\text { positive } \\
\text { Sero- } \\
\text { negative }\end{array}$} & 16 & $6 \cdot 74$ & $2 \cdot 88$ & $0 \cdot 38$ & 0.85 & $0 \cdot 82$ & $1 \cdot 81$ & 19 & $4 \cdot 6$ & $2 \cdot 03$ & $0 \cdot 27$ & 0.4 & $0 \cdot 5$ & $1 \cdot 41^{*}$ \\
\hline & & 9 & $7 \cdot 13$ & $2 \cdot 93$ & 0.35 & 0.84 & 0.87 & $2 \cdot 11$ & 13 & $5 \cdot 0$ & $2 \cdot 03$ & $0 \cdot 2$ & $0 \cdot 33$ & 0.51 & $1 \cdot 91$ \\
\hline
\end{tabular}

* + Significant differences indicated as in Table II.

fluid gamma globulin levels (Fig. 1). Even this correlation could be regarded as no more than suggestive.

\section{Ankylosing Spondylitis}

The impressive feature of both serum and synovial fluid from these patients was the very much higher mean gamma globulin level compared with the level in patients with rheumatoid arthritis (Table II). Even if the cases of ankylosing spondylitis were compared with patients who had suffered from rheumatoid arthritis for more than 5 years, the gamma globulin levels were still significantly higher in the former. Another difference was the significantly higher alpha ${ }_{2}$ globulin level in serum and synovial fluid in ankylosing spondylitis. The increase in these two fractions accounts for the very much higher serum and synovial fluid total protein levels in these cases.

Since the histological features of ankylosing spondylitis were indistinguishable from those of rheumatoid arthritis, the synovial biopsies taken from the spondylitics have been included in Fig. 1 for comparison with the synovial fluid gamma globulin levels.

\section{Reiter's Syndrome}

No case presented the classical triad but all had coincidental arthritis of less than 3 months' duration and urethritis. The serum and synovial fluid protein patterns did not differ significantly from those found in rheumatoid arthritis. Nor did the

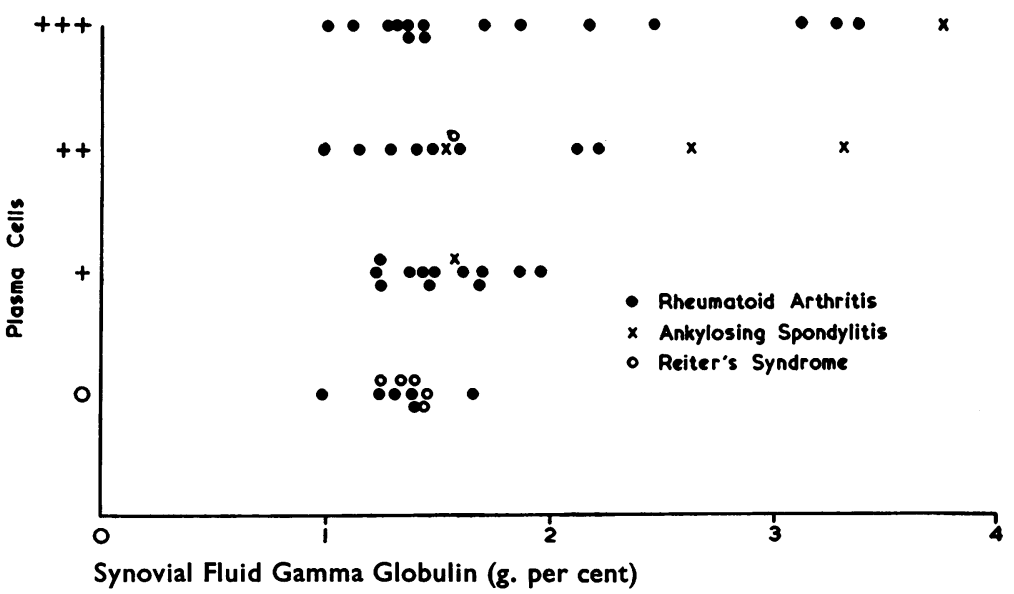

Figure.-Degree of plasma cell infiltration of synovial membrane correlated with synovial fluid gamma globulin content in rheumatoid arthritis, ankylosing spondylitis, and Reiter's syndrome. There is a tendency for the heavier infiltrations to correspond with higher gamma globulin levels. 
synovial biopsies show any distinguishing features and for this reason they have been included in Fig. 1.

\section{Discussion}

There seem to be two main types of synovial fluid protein pattern: the osteo-arthritic, perhaps better called non-specific, and the rheumatoid.

In osteo-arthritis, traumatic synovitis, and in the few cases we have studied of neuropathic arthritis, gout, and the arthropathies associated with leukaemia, sarcoidosis, and myelomatosis, the synovial fluid protein pattern has mimicked that of the serum with only slight differences explainable by the poorer penetration of the larger globulin molecules into the synovial fluid. This type of synovial fluid has invariably been associated with the histological picture of non-specific synovitis, in which the most constant feature is the paucity of infiltrating chronic inflammatory cells (Wilkinson and Jones, 1963).

At the onset of the effusion in osteo-arthritis the serum and synovial fluid changes are very similar to those seen in traumatic synovitis and perhaps this is not surprising if one considers that osteoarthritis probably renders a joint less stable and more subject to minor injuries. There is an immediate modest rise in the serum alpha $a_{2}$ and gamma globulins and a reversal towards normal within a few weeks. Similar changes are seen in the synovial fluid. Such changes are common to many acute inflammatory diseases and the very promptness of the gamma globulin rise suggests an outpouring of non-specific antibody rather than an antibody response to dead tissue somehow rendered antigenic by the traumatic insult.

The second type of synovial fluid protein pattern is common to rheumatoid arthritis, ankylosing spondylitis, and Reiter's syndrome. Here the synovial fluid pattern resembles the serum pattern except in one respect, viz. the synovial fluid pattern is distorted by a relative excess of gamma globulin. Whereas, in the osteo-arthritic type of effusion, the gamma globulin level is approximately 50 per cent. of the serum level, in the rheumatoid type it is 70 per cent. or more. If the relative concentration of each protein fraction in the serum and synovial fluid is taken only as an indication of the permeability of the synovial membrane to that fraction, then in the rheumatoid disorders the membrane would appear more permeable to gamma globulin than to the much smaller albumin molecule. This hardly seems likely, especially when one considers the findings in osteo-arthritis where, as one would expect, the synovial membrane appears to be less permeable to gamma globulin than to albumin.
It seems not unreasonable to suggest that the disproportionately high gamma globulin content of rheumatoid synovial fluid is due to the continuous local release of gamma globulin by the plasma cells. This suggestion is supported by our histological findings, for the synovial fluid protein pattern of rheumatoid arthritis, ankylosing spondylitis, and Reiter's syndrome is associated with the same rheumatoid histological picture in the synovial membrane, and this includes among other features a variable infiltration with lymphocytes and plasma cells. Although the correlation is only suggestive, it appears that the heavier plasma cell infiltrations are associated with higher synovial fluid gamma globulin levels.

The changes in the protein pattern with increasing duration of disease also differ in rheumatoid arthritis. Whereas, in osteo-arthritis, the serum protein changes occur promptly and rapidly revert towards normal, in rheumatoid arthritis they occur more slowly over a much longer period. The initially low serum albumin rises towards normal but remains slightly low, the alpha $a_{1}$ globulin remains high, the initially very high alpha $a_{2}$ globulin falls considerably (but not to normal levels), and the gamma globulin (which in the serum does not show the prompt rise seen in osteo-arthritis) rises to moderately high levels especially after the first 3 months of the disease. Similar changes are seen in the synovial fluid, but the albumin rise is slightly more marked (possibly indicating greater synovial inflammation and permeability with increasing duration of disease) and the gamma globulin is disproportionately high at all stages of the disease in active cases.

One can only speculate on the causes of the higher gamma globulin levels in sero-negative rheumatoid arthritis as compared with sero-positive cases. An obvious explanation would be that, in the seropositive cases, rheumatoid factor which in vivo circulates in loose combination with gamma globulin (Franklin, Kunkel, Müller-Eberhard, and Holman, 1957) may be removed from the circulation with its bound gamma globulin after a survival period much shorter than that of normal gamma globulin. An alternative explanation may be that cases with and without rheumatoid fector represent two different disease groups. As Dixon (1960) has pointed out, sero-negative rheumatoid arthritis is a somewhat heterogeneous entity, and Duthie, Brown, Knox, and Thompson (1957) have shown that the prognosis in this group is better than in the sero-positive cases. Every effort was made to ensure accurate diagnosis, but it is possible that the sero-negative cases include a few examples of such 
conditions as psoriatic arthropathy without skin lesions (Baker, Golding, and Thompson, 1963) and Reiter's syndrome, in which the urethritis has been long forgotten or not admitted. In view of the higher gamma globulin levels in ankylosing spondylitis, one might wonder whether any such cases are included among the sero-negative rheumatoid arthritics. This seems most unlikely for all were examined with this in mind and many had negative sacro-iliac $x$ rays.

The cause of the protein changes in rheumatoid arthritis remains obscure. The low serum albumin, so common in chronic diseases, is unlikely to be due to excessive protein loss or destruction, so that one is tempted to believe that amino acids are being claimed for the excessive globulin synthesis leaving less available for albumin production. In the early stages of the disease, adrenal response to stress may be another factor. Mackiewicz and Fenrych (1961) have demonstrated excess alpha ${ }_{1}$ glycoprotein and alpha $_{2}$ globulin including haptoglobin in both the serum and the synovial fluid of rheumatoid patients. Since the synovial fluid serum ratios of these substances are not disproportionately high, Nettelbladt and Sundblad (1961) suggest that this excess of alpha $_{1}$ and alpha $_{2}$ globulins is more probably due to excessive production by the liver in response to inflammation, rather than to release from sites of tissue destruction in the inflamed synovial membrane.

By far the most impressive abnormality of the proteins in rheumatoid arthritis is the progressive rise in the gamma globulin, especially in the synovial fluid. This, together with the synovial histology, suggests a persistant stimulus to antibody production by some antigen in the region of the synovial membrane, though it is impossible to decide at present whether this is of aetiological importance or is simply a reaction to injured or necrotic tissue present in the rheumatoid joint.

No explanation can be offered for the higher alpha $_{2}$ and gamma globulin levels in the serum and synovial fluid of patients with ankylosing spondylitis. Our cases were mostly patients with longstanding arthritis of the spine and one or both knees, but there was no clinical evidence to suggest that the arthritis was of exceptional severity.

\section{Summary}

The results of protein electrophoretic estimations on 150 synovial fluids have been analysed. Two main patterns have been found.

In osteo-arthritis, traumatic synovitis, and other non-rheumatoid disorders, the synovial fluid protein pattern resembles that of the serum and in these cases synovial biopsies consistently showed nonspecific synovitis. Osteo-arthritic patients with recent effusions and cases of traumatic synovitis showed higher alpha ${ }_{2}$ and gamma globulin levels in both serum and synovial fluid than did osteoarthritics with long-standing effusions.

The synovial fluid protein pattern in rheumatoid arthritis, ankylosing spondylitis, and Reiter's syndrome resembled the serum pattern except for a considerable excess of gamma globulin. In these diseases synovial biopsies showed the same rheumatoid pattern and the intensity of plasma cell infiltration seemed to correlate with the synovial fluid gamma globulin content. With increasing duration of rheumatoid arthritis both serum and synovial fluid showed a slight rise in albumin, persistently high alpha $a_{1}$, falling alpha $a_{2}$, and rising gamma globulin levels.

In cases of rheumatoid arthritis of more than one year's duration sero-negative patients showed significantly higher synovial fluid and suggestively higher serum gamma globulin levels than did seropositive patients.

Cases of ankylosing spondylitis with peripheral arthritis showed very significantly higher alpha and gamma globulin levels in serum and synovial fluid than did cases of rheumatoid arthritis.

We thank the Charing Cross Hospital Research Committee for their continued support during this study and Mr. J. Miller for his assistance with the biopsy material.

\section{REFERENCES}

Baker, H., Golding, D. N., and Thompson, M. (1963). Brit. med. J., 2, 348.

Cruickshank, B. (1952). Ann. rheum. Dis., 11, 137.

Dixon, A. St. J. (1960). Ibid., 19, 209.

Duthie, J. J. R., Brown, P. E., Knox, J. D. E., and Thompson, M. (1957). Ibid., 16, 411.

Franklin, E. C., Kunkel, H. G., Müller-Eberhard, H. J., and Holman, H. R. (1957). Ibid., 16, 315.

Mackiewicz, S., and Fenrych, W. (1961). Ibid., 20, 265.

Nettelbladt, E., and Sundblad, L. (1961). Arthr. and Rheum., 4, 161.

Ropes, M. W., Bennett, G. A., Cobb, S., Jacox, R., and Jessar, R. A. (1959). Ann. rheum. Dis., 18, 49.

Wilkinson, M., and Jones, B. S. (1962). Ibid., 21, 51.

—— (1963). Ibid., 22, 100.

\section{DISCUSSION}

Dr. A. St. J. Dixon (Kensington): I should like to congratulate Dr. Wilkinson, but I wonder whether some other factors ought not to be considered. What I have in mind arises out of some experiments carried out by Dr. Grant and his colleagues in Buffalo. Normal and rheumatoid knees were injected with serum and it was noticed that the serum disappeared much more rapidly 
from the rheumatoid knee than from the normal knee; this rate of disappearance was observed in the absence of rupture, and was much greater after exercise. The work of Dr. Wilkinson assumes that the factor which causes the plasma proteins to enter the synovial fluid is the same as that which causes it to go out. I do not think this is necessarily true. There is accumulation of $\gamma$ globulin in inflammatory joint conditions, and it might be easier for the $\gamma$ globulin to get in than to get out. If there are different ways by which it enters-by simple dialysis or diffusion-it may get out by a process which relies on pressure and sieves out the molecules which have greater difficulty in getting out under pressure. Do you think this should be considered, and that some of these experiments should be done on patients who are in fact immobilized?

DR. WILKInson: It is a possible explanation, I suppose. There is protein and fluid coming in all the time, and protein going out, mcstly through the lymphatics. It is possible that $\gamma$ globulin is fixed in the joint, but why should $\gamma$ globulin be fixed in the joint and $\alpha_{1}$ and $\alpha_{2}$, which have larger molecules, not be selectively fixed in the joint?

Prof. E. G. L. Bywaters (Hammersmith): In support of Dr. Dixon's remarks, I was very much impressed by this work, but I am not convinced by Dr. Wilkinson's explanation. I am sure we must regard this as a poolthings coming in and things going out! What sort of contribution local production makes, I think, is far from clear. It is certainly possible, but I cannot see that this present information throws any light on whether $\gamma$ globulin is produced locally and extruded into the joint. I think the major correlations were between the concentration of total serum protein and that of synovial $\gamma$ globulin as in the ankylosing spondylitics.

DR. WILKINSON: The total protein only reflected that the $\gamma$ globulin was high.

DR. J. S. LAWRENCE (Manchester): I have not compared sero-positives and sero-negatives, but I have noticed that in the patients with rheumatoid arthritis, most of whom were sero-positive, the $\gamma$ globulin level was mostly lower than in those with other inflammatory diseases. Have you not found instances in which the $\gamma$ globulin was higher in the synovial fluid than in the serum?

DR. WILKINSON: There are one or two in which it is a little higher, but with such a crude method of estimating $\gamma$ globulin, one would hesitate to deduce too much from a few observations.

Etudes électrophorétiques des protéines du liquide synovial

\section{RÉSUMÉ}

On analysa les résultats des déterminations électrophorétiques des protéines dans 150 liquides synoviaux. On trouva deux tableaux principaux.

Dans l'ostéoarthrite, la synovite traumatique et dans d'autres désordres non-rhumatismaux le tableau protéique du liquide synovial ressemble celui du sérum et en ces cas les biopsies synoviales montraient régulièrement l'existence d'une synovite non spécifique. Des malades atteints d'ostéoarthrite avec épanchements récents et ceux atteints de synovite traumatique accusaient des taux plus élevés de globuline alpha $a_{2}$ et gamma dans le sérum et dans le liquide synovial que des cas d'ostéoarthrite avec épanchements anciens.

Le tableau protéique du liquide synovial des cas d'arthrite rhumatismale, de spondylarthrite ankylosante et de syndrome de Reiter ressemble celui du sérum, sauf un excés considérable de globuline gamma. Dans ces maladies les biopsies synoviales montrent le même tableau rhumatismal et l'intensité de l'infiltration par des plasmocytes semble correspondre au contenu du liquide synovial en globuline gamma. Pendant que l'arthrite rhumatismale continue à évoluer, tant le sérum que le liquide synovial accusent une augmentation légère du taux d'albumine et la persistance de la globuline alpha élevée, de la alpha ${ }_{2}$ diminuante et de la gamma augmentante.

En des cas d'arthrite rhumatismale existante depuis plus d'un an, les malades séro-négatifs accusaient des taux de globuline gamma appréciablement plus élevés dans le liquide synovial et un peu plus élevés dans le sérum que les malades séro-positifs.

Des cas de spondylarthrite ankylosante avec une arthrite périphérique accusaient des taux appréciablement plus élevés de globuline alpha $a_{2}$ et gamma dans le sérum et le liquide synovial que des cas d'arthrite rhumatismale.

\section{Estudios electroforéticos de las proteinas del líquido sinovial}

\section{SUMARIO}

Se analizaron los resultados de las determinaciones electroforéticas de las proteinas en 150 líquidos sinoviales. Se observaron dos cuadros principales.

En la osteoartritis, la sinovitis traumática y en otros disturbios non reumáticos el cuadro proteínico del líquido sinovial se parece al del suero y en tales casos biopsias sinoviales revelaban regularmente la existencia de una sinovitis no específica. Enfermos con osteoartritis y derrames recientes y los con sinovitis traumática acusaban cifras más altas de globulina alfa $_{2}$ y gamma en el suero y en el líquido sinovial que los con osteoartritis y derrames más viejos.

El cuadro proteico del líquido sinovial de casos de artritis reumatoide, espondilartritis anquilosante y sindrome de Reiter se parece al del suero, con excepción de un exceso considerable de globulina gamma. $\mathrm{nE}$ estas enfermedades biopsias sinoviales muestran el mismo cuardo reumático y la intensidad de la infiltración por plasmocitos parece corresponder al contenido de la globulina gamma en el líquido sinovial. Mientras que la artritis reumatoide evolua, tanto en el suero como en el líquido sinovial la albumina aumenta un poco, la globulina alfa $a_{1}$ queda elevada, la alfa ${ }_{2}$ sigue disminuyendo y la gamma aumentando.

En casos de artritis reumatoide en existencia desde más de un año, los enfermos sero-negativos acusaban cifras de globulina gamma significativamente más elevadas en el líquido sinovial y sugestivamente más altas en el suero que los enfermos sero-positivos.

Casos de espondilartritis anquilosante con artritis periférica acusaban cifras significativamente más altas de globulina alfa $a_{2}$ y gamma en el suero y en el líquido sinovial que casos de artritis reumatoide. 